\title{
Misuse of the Kjeldahl Method for Estimating Protein Content in Plant Tissue
}

\author{
Shahrokh Khanizadeh ${ }^{1}$ \\ Agriculture and Agri-Food Canada, Research Station, 430 Boulevard Gouin, St-Jean-sur-Richelieu, Que. J3B 3E6, \\ Canada and Department of Plant Science, McGill University, Ste-Anne-de-Bellevue, Que. H9X 3V9, Canada \\ Deborah Buszard ${ }^{2}$ \\ Department of Plant Science, McGill University, Ste-Anne-de-Bellevue, Que. H9X 3V9, Canada \\ Constantinos G. Zarkadas ${ }^{3}$ \\ Plant Research Centre, Research Branch, Agriculture and Agri-Food Canada, Ottawa, Ont. K1A 0C6, Canada
}

\begin{abstract}
Accurate plant protein analysis is difficult, primarily because of the small amounts of proteins present in the tissue and partly due to the interference of other complex plant constituents (Agustí and Beltrán, 1982; Khanizadeh et al., 1989, 1992a; Marks et al., 1985; Robinson, 1979). Many procedures have been used for protein determination in plant tissues. The most commonly used procedures for total protein estimation are: folin phenol (Lowry et al., 1951), biuret (Gornall and Bardawill, 1949), 280/260 nmultraviolet(UV) absorption, improved 224-236 nm isoabsorbance (Groves et al., 1968), 280/205 nm absorption (Scopes, 1974), coomassie blue dye binding (Bradford, 1976), and classical Kjeldahl [Association of Official Analytical Chemists (AOAC), 1984; Morries, 1983]. However, some of these methods (e.g., folin phenol, Bradford and UV absorption, and biuret) cannot be used for plant tissue due to the presence of numerous interfering compounds, such as phenolics, tannins, and alkaloids (Benedict, 1987; Marks et al., 1985; Peterson, 1983; Robinson, 1979). Others, such as the spectrophotometric method of Warburg and Christian (1942) and Waddell and Hill (1956), cannot distinguish between protein and plant nucleic acid content (Groves et al., 1968). The biuret reaction is also subject to ammonia, tris, and glycerol interference (Bradford, 1976). Peterson (1983) examined various methods of protein determination based on their relative sensitivity for bovine serum albumin and a range of proteins. He concluded
\end{abstract}

\footnotetext{
Received for publication 17 Apr. 1995. Accepted for publication 10 July 1995 . Contribution no. 335/ 95.06.02R from Agriculture Canada and 1592 from the Plant Research Centre. Viewpoints are published in HortScience to provide Members of the American Society for Horticultural Science an opportunity to share their experiences and comments on matters of concern to horticulturists. These are not statements of official Society policy, nor do they necessarily reflect the views of a majority of the Society's Members. The cost of publishing this paper was defrayed in part by the payment of page charges. Under postal regulations, this paper therefore must be hereby marked advertisement solely to indicate this fact.

${ }^{1}$ Research Scientist and Assistant Professor, Breeder and Physiologist.

${ }^{2}$ Associate Professor, Pomologist.

${ }^{3}$ Research Scientist, Biochemist.
}

that all spectrophotometric methods are similar in sensitivity, but more sensitive than biuret, 280-nm UV absorption, or turbidimetric methods. He also reported that procedures that are simple to perform usually give relative rather than absolute protein quantitations. In general, he suggested reliable estimates of the absolute amount of protein may be obtained by quantification of total amino acids. Agustí and Beltrán (1982) compared the three spectrophotometric methods of Lowry et al. (1951), Bradford (1976), and Flores (1978), and used Kjeldahl as a reference. They measured higher amounts of proteins by using the three spectrophotometric methods than by using the Kjeldahl procedure.

Of the above methods, Kjeldahl analysis and subsequent estimation of protein by multiplying total $\mathrm{N}$ by 6.25 is the most frequently used procedure, owing to its simplicity and low cost. Workers assume that all plant proteins have a mean N content of $16 \%$. However, the Kjeldahl method does not distinguish between protein $\mathrm{N}$, free amino acid $\mathrm{N}$, or other nitrogenous compounds, such as inorganic $\mathrm{N}$, alkaloids, cyanogenic glycosides, amides, ammonium salts, nitrogenous glucosides, porphyrins, fats, hormones, nucleic acids, etc. Therefore, the conversion factor of 6.25 is inexact and results in overestimation of total protein in most plant tissue (Khanizadeh et al., 1992b; Milton and Dintzis, 1981). We believe that a specific conversion factor should be calculated for each tissue to estimate total protein content accurately, given that total nonprotein $\mathrm{N}$ content varies from plant to plant, between different tissues on the same plant, and even in the same tissue at different stages of growth and development (Jones, 1931, 1991; Jones et al., 1991; Khanizadeh et al, 1989; Milton and Dintzis, 1981). While the factor of 6.25 is widely used for many plant tissues, specific factors for total protein determination have been developed for many crops. For example, 5.71 for wheat-flour (Triticum aestivum L.), 5.18 for almonds (Prunus amygdalus Batsch.), 5.46 for peanuts (Arachis hypogaea L.) and Brazil nuts (Bertholltica excelsa Humb. and Bonpl.), 5.3 for tree nuts and coconuts (Cocos nucifera L.), 4.4 for tropical plant samples, and 5.51 for apple (Malus pumila Borkh.) flower bud tissue, etc. (AOAC, 1980, 1984; Benedict, 1987; Heidelbaugh et al., 1975; Jones, 1931; Khanizadeh et al., 1992b; Milton and Dintzis,
1981). Jones (1931) proposed individual conversion factors for many plants and food products.

Several techniques have been proposed as alternatives to the Kjeldahl procedures: 1) Dumas combustion, which determines total N (Hansen, 1989); 2) near-infrared reflectance spectrometry, which gives results similar to the Kjeldahl procedure, since the method is based on the approximate relationship between $\mathrm{N}$ and protein content (Jones, 1991); and 3) amino acid analysis using the ninhydrin reaction in which the protein content is measured by total amino acid composition using ion exchange columns (Horstmann, 1979; Khanizadeh et al., 1992b). The estimation of total protein is based on the summation of amino acid $\mathrm{N}$ after breaking the peptide bonds by acid hydrolysis and passing the amino acids through the column. Once total amino acid N has been determined, a conversion factor can be calculated (Khanizadeh et al., 1992b; Milton and Dintzis, 1981). This factor can be used for subsequent protein determination in tandem with the Kjeldahl method (Khanizadeh et al., 1992b). However, even the use of conversion factors based on total amino acid $\mathrm{N}$ analysis still gives an erroneous protein content estimate when used with Kjeldahl total $\mathrm{N}$ analysis because of the variation of nonprotein nitrogenous compounds during growth and development (Khanizadeh et al., 1992b).

While the Kjeldahl method is recognized as accurate and precise for total $\mathrm{N}$ determination, its application for protein assay in plant materials has been questioned by many investigators (Benedict, 1987; Heidelbaugh, 1975; Jones, 1991; Jones et al., 1991; Khanizadeh et al., 1992b; Milton and Dintzis, 1981).

In summary, because of the small amount of protein present in most plant materials and the existence of many interfering substances, amino acid analysis is the best technique for precise determination of plant protein. This method seems the most reliable for plant tissues and is independent of the type of protein or tissue. It can be used for fresh or dried materials with very low protein content (Horstmann, 1979; Khanizadeh et al., 1989; Marks et al., 1985; Moore and Stein, 1948; Spies, 1957). It is suitable for soluble (i.e., free amino acids, oligopeptides, amino sugars) and insoluble proteins (i.e., cell wall glycoproteins) that are present in large amounts in all plant tissue (Heidelbaugh et al., 1975; 
Horstmann, 1979; Khanizadeh et al., 1989). An added advantage of amino acid analysis using the ninhydrin reaction is the lack of interference by phenolics, tannins, and lignins, which are universally present in plants, often in high concentrations (Khanizadeh etal., 1989, 1992b; Lommis, 1974; Marks et al., 1985). Furthermore, free amino acid content can be measured using the unhydrolyzed methanol extracts of plant samples (Marks et al., 1985). In short, Kjeldahl is not an accurate method for estimating protein content in plant tissue, no matter what the conversion factor is, while amino acid analysis provides a direct measurement of protein in plant tissue rather than an estimation from total $\mathrm{N}$ values.

\section{Literature Cited}

Agustí, J.A. and J.P. Beltrán. 1982. Quantitative determination of the protein content of citrus leaf extracts: A comparative study. Anal. Biochem. 127:368-371.

Association of Official Analytical Chemists. 1980 Official methods of analysis. 14th ed. Assn. Official Analytical Chemists, Washington, D.C. sec. 7.015.

Association of Official Analytical Chemists. 1984. Official methods of analysis. 14th ed. Assn. Official Analytical Chemists, Arlington, Va. sec. 14.067.

Benedict, R.C. 1987. Determination of nitrogen and protein content of meat and meat products. J. Assn. Official Analytical Chem. 70(1):69-74.

Bradford, N.M. 1976. A rapid and sensitive method for the quantitation of microgram quantities of protein utilizing the principle of protein-dye binding. Anal. Biochem. 72:248-254.

Flores, R. 1978. A rapid and reproducible assay for quantitative estimation of proteins using bromophenol blue. Anal. Biochem. 88:605-611.
Gornall, A.G. and C.J. Bardawill. 1949. Determination of serum protein by the means of the biuret reaction. J. Biol. Chem. 177:751-766.

Groves, W.E., F.L. Davis, and B.H. Shells. 1968. Spectrophotometric determination of microgram quantities of protein without nucleic acid interference. Anal. Biochem. 22:195-210.

Hansen, B. 1989. Determination of nitrogen as elementary N, an alternative to Kjeldahl. Acta Agr. Scand. 39:113-118.

Heidelbaugh, N.D., C.S. Huber, J.F. Bednarczyk, M.G. Smith, P.C. Rambart, and H.O. Wheeler. 1975. Comparison of three methods for calculating protein content in foods. J. Agr. Food Chem. 23:611-613.

Horstmann, H.J. 1979. A precise method for the quantitation of protein taking into account their amino acid composition. Anal. Biochem. 96:130-138.

Jones, B.D. 1931. Factors for converting percentage of nitrogen in foods and feeds into percentages of proteins. U.S. Dept. of Agr. Circ. 183. Washington, D.C.

Jones, Jr., B.J. 1991. Kjeldahl method for nitrogen determination. Micro-Macro Publishing, Athens, Ga.

Jones, Jr., B.J., B. Wolf, and H.A. Mills. 1991. Plant analysis handbook: A practical sampling, preparation, analysis, and interpretative guide. MicroMacro Publishing, Athens, Ga.

Khanizadeh, S., D. Buszard, and C.G. Zarkadas. 1989. Seasonal variation of proteins and amino acids in apple flower buds (Malus pumila Mill. cv. McIntosh/M7). J. Agr. Food Chem. 37:12461252.

Khanizadeh, S., D. Buszard, and C.G. Zarkadas. 1992a. Effect of crop load on hardiness, protein and amino acid content of apple flower buds at wintering stage and the beginning of the growth J. Plant Nutr. 15(11):2441-2455.

Khanizadeh, S., D. Buszard, and C.G. Zarkadas. 1992b. Comparison of three methods for calculating protein content in developing apple flower buds. J. Assn. Official Analytical Chem. 75(4):734-737.

Lommis, W.D. 1974. Overcoming problems of phenolics and quinones in the isolation of plant enzymes and organelles, p. 528-545. In: S. Fleischer and L. Packer (eds.). Methods in enzymology. vol. 31. Academic, New York.

Lowry, O.L., N.J. Rosebrough, A.L. Farr, and R.S. Randall. 1951. Protein measurement with the folin phenol reagent. J. Biol. Chem. 193:265-275.

Marks, D.L., R. Buchsbaum, and T. Swain. 1985. Measurement of total protein in a plant sample in the presence of tannins. Anal. Biochem. 147:136-143.

Milton, K. and F.R. Dintzis. 1981. Nitrogen-toprotein conversion factors for tropical plant samples. Biotropica 13(3):177-181.

Moore, S. and W.H. Stein. 1948. Photometric ninhydrin method for use in the chromatography of amino acids. J. Biol. Chem. 176:367-388.

Morries, P. 1983. A century of Kjeldahl (18831983). J. Assn. Public Analysts 21:53-58.

Peterson, G.L. 1983. Determination of total protein, p. 95-119. In: C.H.W. Hirs and S.N. Timasheff (eds.). Methods in enzymology. vol. 91. Academic, New York.

Robinson, T. 1979. The determination of proteins in plant extracts that contain polyphenols. Plant Sci. Lett. 15:211-216.

Scopes, R.K. 1974. Measurement of protein by spectrophotometry at $205 \mathrm{~nm}$. Anal. Biochem. 59:277-282.

Spies, J.R. 1957. Colometric procedures for amino acids, p. 467-477. In: S.P. Clowick and N.O. Kaplan (eds.). Methods in enzymology. vol. 3. Academic, New York.

Waddell, W.J. and C. Hill. 1956. A simple ultraviolet spectrophotometric method for the determination of protein. J. Lab. Clinical Med. 48:311314.

Warburg, O. and W. Christian. 1942. Isolierung und Kristallisation des Gärungsferments Enolase. Biochemische Zeitsch. 310:384-421. 